\title{
Applying Real Options Analysis to Value the GM-Fiat Strategic Joint Venture
}

\author{
Octavian Ionici ${ }^{1}$ \\ Department of Finance \\ Loyola College in Maryland \\ Sellinger School of Business and Management \\ Baltimore, MD 21210 \\ 410-617-5634 \\ oionici@loyola.edu
Kenneth Small
Department of Finance
Loyola College in Maryland
Sellinger School of Business and Management
Baltimore, MD 21210
410-617-5210
ksmall@loyola.edu
Steve Kramer
Department of ISOM
Loyola College in Maryland
Sellinger School of Business and Management
Baltimore, MD 21210
410-617-2948
skramer@loyola.edu

${ }^{1}$ Corresponding author 


\title{
Applying Real Options Analysis to Value the GM-Fiat Strategic Joint Venture
}

\begin{abstract}
In the year $2000 \mathrm{GM}$ and Fiat entered a strategic joint venture of shareholding and management power. The executives of both companies designed a tactical joint venture contract characterized by flexible options. Flexibility was critical for a long-term investment in the dynamic auto industry environment. A key question was how to value this flexibility. An analysis on the joint venture provides an interesting insight into the investment decision as a real option. Because of a reported high-failure rate in the joint venture deals, this paper also discusses the drivers and underlying problems that affect the operation of joint ventures. We apply real options analysis to value the strategic alliance between GM and Fiat ${ }^{2}$. We also highlight some of the problems related to the inherent flexibility embedded in the GM-Fiat agreement. As a result, we suggest the need to create a customized model which mitigates the conflict between the conclusion of strategic analysis and a real option approach.
\end{abstract}

\section{Working Draft \\ Please do not Quote or Disseminate without Permission}

\footnotetext{
${ }^{2}$ The GM-Fiat case serves as the basis for discussion rather than to illustrate either effective or ineffective handling of an administrative situation
} 


\section{Introduction}

Flexibility is one of the key attractions of joint ventures (JV) and strategic alliances. ${ }^{3}$ They can be shaped in various ways to suit the specific needs of the partners and markets. If companies have a merger or acquisition objective, a strategic alliance is a valuable step in affecting the acquisition performance. ${ }^{4}$ Thus, an acquirer firm can gradually gather target-specific information and experience that might be an advantage in the valuation and integration of a target company. ${ }^{5}$

A joint venture is defined as a form of partnership where businesses come together to share markets, skills, knowledge and resources through a new organizational unit. The new legal entity has an objective of maximizing profits and pursuing strategic advantages. A number of studies showed that companies engage in joint ventures to increase market power ${ }^{6}$ as well as to stabilize competition ${ }^{7}$. Arguing that joint ventures are motivated by synergies, McConnell and Nantell (1985) concluded that they are carried out for efficiency reasons. Jemison (1986) also emphasized that value creation in mergers and acquisitions is achieved by gaining operating synergies. Although there is no question that both academics and practitioners view synergies as the source of value creation in mergers and acquisitions, the empirical evidence shows that most acquisitions produce little synergies. ${ }^{8}$ While synergies might be the predominant factor, acquisitions

\footnotetext{
${ }^{3}$ Although not all business alliances should be considered joint ventures, for this paper the terms "joint venture, "strategic alliance", "partnership" are used interchangeably

${ }^{4}$ Reich and Mankin (1984), Bleeke and Ernst (1995), Hagedoorn and Sadowski (1999), Chang and Rosenzweig (2001)

${ }^{5}$ Schildt and T. Laamanen (2006)

${ }^{6}$ Pate (1969), Boyle (1968), Mead (1967)

${ }^{7}$ Berg and Friedman (1978a)

${ }^{8}$ Singh \& Montgomery (1987), Sirower (1997).
} 
are also driven by other potential complementary objectives related to products, technologies and the geographical market factors.

To manage the dependency of the partner companies and to develop mechanisms to exploit uncertainties, partner firms design strategic clauses which are stipulated in a formal joint venture agreement. A formal agreement is necessary to provide ways of preserving the stability of the joint venture, and to keep the parties from deviating from specified targets. ${ }^{9}$ In the view of Gutterman (2002), the basic structure of a joint venture agreement consists of the following three components: (i) each party's initial contribution; (ii) the corresponding percentage of ownership in the joint venture and (iii) allocation of profits and losses in the new entity. The restatement of ownership and termination clauses also represents important components of a joint venture contract. Other clauses that also give the partner firms specific rights are the tag-along rights, dragalong rights, piggy-back rights, catch-up clauses ${ }^{10}$ and Put and Call options. ${ }^{11}$ Those option-like rights based on Put and Call options give companies the right, but not the obligation to take some actions in the future while reducing the downside risks. Because these clauses regulate the transfer of rights between partner firms, they share the features of real options.

For the past two decades, real options received a lot of attention in academic literature. Real options are applicable in many areas of decision making under risk such as corporate finance, technology adoption, climate change, research and development,

\footnotetext{
${ }^{9}$ Harrigan, (1986)

${ }^{10}$ Tag-along rights allow parties to demand the same treatment as received by their partners; drag-along rights allow parties to force their partners to join them in selling their stakes in the case of a trade sale; piggy-back rights permit parties to demand to be included in an IPO according to their stakes in the corporation

${ }^{11}$ Chemla et al. (2004), Herzfeld and Wilson (1996), Linklaters et al. (1990)
} 
project valuation and biodiversity decisions. Real options models have increasingly been used in a variety of settings, including oil and gas exploration, e-business, start-ups, venture capital investments, licenses, mergers, intangibles valuation and other business activities operating in dynamic and uncertain business environments. Insights from options-based analyses improved not only the estimates of project value, but also the decision making process.

The essential paradigm for making decisions about large investments is NPV. However, numerous studies have showed that standard discounted cash flow valuation methodologies (NPV) can not adequately capture the value of managerial flexibility to grow, expand, wait, scale down or abandon projects. Therefore, real options analysis is recommended as a strategic decision making tool because it allows explicitly to value management's flexibility. ${ }^{12}$ Dixit and Pindyck (1994), Trigeorgis (1996) and Amran and Kulatilaka (1999b) provide a methodology and discuss the application of option valuation concepts to investment decisions under high uncertainty. Among others, Kester (1984), Mason and Merton (1985) and Trigeorgis and Mason (1987) also suggest the use of options based models to value managerial flexibility in investment opportunities. Although, theoreticians have been covering real options analysis for quite sometime, still few companies apply this approach. ${ }^{13}$ Yet, in spite of this new interest, little work was focused on analyzing joint ventures as real options. To derive the optimum exercise time for an acquisition Kogut (1991) uses real options analysis and shows that joint ventures appear to be used as an intermediary step towards a complete acquisition. Chi and

\footnotetext{
${ }^{12}$ Smith (2003)

${ }^{13}$ Coy (1999)
} 
McGuire (1996) apply options valuation methodology to explicit options secured in joint venture agreements.

In order to analyze the thought process and valuation of an acquisition we consider two firms that initially form a joint venture. Thus, the managers of the acquirer firm decide to expand into new market by acquiring a target firm. In doing so, both firms agree to form a joint venture and after a number of years the acquirer to acquire the rest of the target firm. Because this type of deal is filled with a high level of uncertainty, a robust contractual agreement and clear strategy are necessary for valuing, justifying and managing this large corporate investment decision. As the uncertainty drives the value of the joint venture and indirectly the value of the acquisition price, both firms decide that the acquirer will acquire only s\% of shares of the target firm when signing the JV contract. From the beginning we have to specify that both firms have also the same goal of establishing a successful joint venture. This collaborative venture allows each party to exchange know-how, to get to know each other closely and gradually to resolve the uncertainty through the passage of time, actions and events (Mun, 2002). A natural question arises about how will these actions and events affect each party's ex-ante assessment of the contractual obligations in the negotiation process. The real options analysis incorporates a learning model and takes into account that managers may change their decisions under expected and unexpected conditions at the appropriate time. So, if the acquirer firm entered into a strategic JV with the target firm by which the acquirer firm to purchase the rest of the firm at a later date, the impact of this decision will have to be captured in the valuation and negotiation process when both parties signed the agreement. The paper aims at contributing to a better explanation and understanding of 
the steps and difficulties in applying the real options approach to valuing a strategic alliance. The outcome to each party depends on quantifiable uncertain future events as reflected in specific clauses stipulated in the JV contract. As an example, we use a real options approach to analyze the complexity of the GM-Fiat joint venture that took place in 2000. The study also focuses on challenges, advantages and drawbacks of real options methodology vis-à-vis conclusions suggested by the strategic reasons. Our analysis shows that a customized options-based model can mitigate the conflict between the conclusion of strategic analysis and a real option approach.

The paper is organized as follows. Section II discusses the value drivers of joint ventures. Section III describes a strategic option model for a joint venture as a step in affecting the acquisition performance. Section IV highlights the auto industry environment and the deal structure between GM and Fiat. Section V details the application of the binomial model technique and reports the results of valuing a strategic Put option. The final section, Section VI, provides a summary and conclusions.

\section{Joint ventures value drivers and real options}

As the research studies suggested in the previous section, an acquisition strategy can be designed by using a joint venture as a learning and educational tool to verify each partner's commitment to a successful deal. Businesses engage in setting up a joint venture for pursuing mutually beneficial opportunities. Although, a formal agreement outlines clear objectives and the strategy to achieve them, sometimes each partner may be tempted to manage the joint venture from a different perspective which can create 
conflicts between the partner firms. In valuing the target firm, we have to value not only the cash flows generated from operations, but also any strategic options that come with the deal.

Kogut's 1988 study on value creation mechanisms of joint ventures highlights the following value drivers:

-enhancement of competitive positioning

-mechanisms to transfer organizational knowledge

-reduction of the transaction costs

Thus, a stronger cooperation between the two partners can lead to higher and faster potential benefits from introducing new strategies and innovations by using common existing infrastructure. The partner firms also target a transfer of technologies as well as a transfer of skillful workers to minimize the costs and maximize the profits of the new entity. If uncertainties can affect the decisions and managers can make appropriate decisions in an uncertain environment, then real options can serve as a tool to hedge the downside risks and take advantage of upside uncertainties.

Based on the evolution of the relationship and market conditions, real options can better prioritize different initiatives for improving the acquisition valuation exercise. Because, this flexibility is not captured with a traditional discounted cash flow analysis, if the acquired firm does not operate up to expectations, an abandonment option can be exercised where the acquirer firm can sell back its initial investment in the target firm or it can sell to a third party its intellectual property and tangible assets. On the other hand, if the target firm is very successful and the joint venture flourishes, an expansion option can be executed where the company can enter new markets or products. While market 
uncertainty is exogenous to investment choices, there is also an endogenous uncertainty that implies greater opportunities for learning. Thus, in a strategic alliance there is an uncertainty over the capabilities of partners $^{14}$ and over the partners' behavior faced with opportunistic tendencies and information asymmetry. ${ }^{15}$

A real option is defined as the right, but not the obligation, to take an action at a pre-determined cost called the exercise price, for a predetermined period of time - the life of the option. ${ }^{16}$ The primary drivers of the value of real options are: the value of underlying asset, exercise price, time to expiration, volatility of the underlying asset and the risk free rate over the life of the option. Thus, the longer the time to expiration, the more time there is for the value of the underlying asset to diverge away from the exercise price. The greater the volatility of asset's returns, the higher the market value of the asset than the exercise price and therefore, the higher the value of the option.

In summary, the significant dimension of a joint venture where both partners are faced with high uncertainty over each others' behavior can be increased by using real options analysis, when strategic options exist in an uncertain environment and management can make the right choices at the right time. Uncertainty represents an important driver for the value of the option to acquire or divest a joint venture.

\section{Description of the strategic model}

This is a simple stochastic model to examine the strategic options embedded into the contract. We'll use a two-stage binomial model based on the financial pricing model

\footnotetext{
${ }^{14}$ Chi \& Seth (2004)

${ }^{15}$ Chi \&McGuire (1996)

${ }^{16}$ Copeland and Antakarov (2001)
} 
by Cox, Ross \& Rubinstein (1979) and on the modeling strategy of Chi and McGuire (1996). Nevertheless, this model assumes a discrete development of the underlying asset value. We'll analyze the model from the acquirer's point of view, but we'll also touch on the conditions and relationship between the target firm and acquirer. From the beginning, both firms know that their collaboration will gradually reveal many aspects which will have an impact on the acquisition value such as their willingness to fully contribute to results as outlined in the agreement. The target firm will especially be tested regarding its responsible behavior and true performance.

Let's define the true value of the target firm by $x$. The value of the underlying asset is assumed to follow a multiplicative binomial distribution, and either increases by $\mathrm{u}$ or decreases by $\mathrm{d}$, taking the value $\mathrm{x}_{\mathrm{u}}$ or $\mathrm{x}_{\mathrm{d}}$ respectively. The two states of nature are mutually exclusive and are realized with risk neutral probabilities $\mathrm{p}$ and (1-p).

$\mathrm{p}=$ probability for $\mathrm{x}_{\mathrm{u}}$ to occur

$1-\mathrm{p}=$ probability for $\mathrm{x}_{\mathrm{d}}$ to occur

The up factor is simply the exponential function of volatility of logarithmic cash flow returns $(v)$ multiplied by the square root of time-steps or stepping times $(\delta \mathrm{t})$. $u=e^{\sigma \sqrt{\delta t}}$ and $d=e^{-\sigma \sqrt{\delta t}}=\frac{1}{u}$

The model has two stages. At $\mathrm{t}=1$ the two firms form a joint venture while at $\mathrm{t}=2$ the uncertainty gets resolved ${ }^{17}$. Let's assume that the acquirer firm makes an initial investment $s I_{0}$ as stipulated in the contract by acquiring s\% of shares of the target firm. $I_{0}$ is the value of the target firm established by negotiation at signing the contract. After the resolution of uncertainty at stage $t=2$, the acquirer firm may decide either to get out of the

\footnotetext{
${ }^{17}$ For a better representation of reality we'll extend our model to a multi-stage binomial model when we'll analyze the GM-Fiat deal
} 
deal if he finds it disadvantageous or to acquire the rest of shares of its partner. The price for the rest of the shares can be determined either at a later date, by negotiations between the two firms or by 4 independent investment banks, or fixed from the beginning.

Let's assume that the price of the rest of the shares (1-s)\% is also set as a multiple of the investment $\mathrm{I}_{0}$ from the beginning when signing the contract. The acquirer firm also holds a Put option to sell out its initial investment $\mathrm{sI}_{0}$ at a prescribed price. By investing only a small amount in the beginning is equivalent to postponing a full investment until significant aspects of uncertainty are resolved. Thus, the acquirer firm can use its resources in other alternative projects while keeping the prospects of future expansion alive. This is in line with the practice in many mergers and acquisitions deals where the use of a Put option is equivalent to an abandonment of the deal at a floor price which is the estimated exercise price of the abandonment option (Copeland and Antikarov, 2003). Thus, real options hedging, applied to mergers and acquisitions, assumes that the initial investment can be returned to the seller if the potential for having a successful merger fails. Our task at hand is to determine the value of the options embedded in the joint venture contract in order to avoid a failed acquisition along with an assessment of the necessary actions and events that affect each party's ex-ante assessment of the contractual obligations in the negotiation process.

The acquirer firm can consider a multiple of $(1-s) I_{0}$ as the maximum fair price willing to pay for acquiring the rest of the shares. At $t=2$, the acquirer firm can be in one of the following scenarios:

1. acquire the shares held by the target firm

2. continue the joint venture 
3. sell the initial investment to its partner (the acquirer will exercise the Put option to return the stock of the seller at the exercise price). The greater the uncertainty about receiving the expected cash flows from the target firm, the more the acquirer is willing to pay for the Put option to find out if entering into a joint venture is worth it.

Let $\beta_{\mathrm{u}}$ denote the bargaining power factor for the acquirer in the up state of nature and $\beta_{\mathrm{d}}$ the bargaining power factor in the down state of nature, respectively.

At stage $t=2$, the acquirer firm's payoff will be:

$$
\begin{aligned}
& v_{\mathrm{u}}=\max \left[\beta_{\mathrm{u}} \mathrm{x}_{\mathrm{u}}-(1-\mathrm{s}) \mathrm{aI}_{0} ; \mathrm{sx}_{\mathrm{u}} ; \mathrm{sbI}_{0}\right] \\
& v_{\mathrm{d}}=\max \left[\beta_{\mathrm{d}} \mathrm{X}_{\mathrm{d}}-(1-\mathrm{s}) \mathrm{aI}_{0} ; \mathrm{sx}_{\mathrm{d}} ; \mathrm{sbI}_{0}\right]
\end{aligned}
$$

where $\mathrm{a}, \mathrm{b}$ are parameters that affect the prices at which the acquirer firm's option can be exercised. So, the end of period payoffs will depend on the value of the underlying risky asset contingent on the state of nature that we are in and on the exercise price of the option.

The acquirer firm will pay this additional premium $a$ to the seller corresponding to the cost of purchasing the rest of the shares held by the target firm, plus any losses from unanticipated changes required for integrating the target firm into the acquirer firm's business as well as a percentage premium of the target value for inducing the target firm's shareholders to sell control.

Parameter $b$ like parameter $a$ is a function of the exercise price, and incorporates any other benefits derived during collaboration. The value of any benefit is viewed differently by the two partners if it is not captured from the beginning in the contract. 
Any anticipated knowledge transfer from the acquirer firm to the target firm can be expected to increase the exercise Put price in the appropriate state of nature. However, if both partners see that the knowledge transfer was fair, this value should be deducted from the exercise price (Chi and McGuire, 1996).

Given the state of nature at moment $t=2$, the acquirer firm will choose the most profitable alternative. Thus, it can get :

- $\quad \mathrm{x}_{\mathrm{u}}-(1-\mathrm{s}) \mathrm{aI}_{0}$ if we are in the $\mathrm{x}_{\mathrm{u}}$ state of nature

- $\quad$ sx by remaining in the joint venture if $\mathrm{x}_{\mathrm{u}}=\mathrm{x}_{\mathrm{d}}=\mathrm{x}$

$\mathrm{sbI}_{0}$ by exercising the Put option if we are in the $\mathrm{x}_{\mathrm{d}}$ state of nature

If we define $\mathrm{dr}$ as the discount rate, $\mathrm{t}$ as time, $\Phi$ as the option premium paid by the acquirer firm to the target firm for the Put option, $v_{u}$ as the payoff in the event of an up condition and $v_{\mathrm{d}}$ in the event of a down condition on the binomial branch, the starting present value or the expected value in continuous time of the binomial tree is:

$V_{0}=\left[p v_{u}+(1-p) v_{d}\right] e^{-d r(t)}-s I_{0}-\Phi$

Where $p=\frac{e^{d r(t)}-d}{u-d}$ is the risk neutral probability and represents the solution for the probabilities on a binomial lattice. The time is simply the time-steps between nodes where we denote $t$ as $\delta$. This probability is used in a risk neutral world where risks have been accounted for and $\mathrm{dr}$ is simply the risk free rate $\mathrm{r}_{\mathrm{f}}$. Replacing the value we get the binomial equation

$$
p=\frac{e^{r_{f}(\delta t)}-d}{u-d}
$$


If there are continuous streams of dividend present, this risk free rate is modified to the risk free rate minus dividend yield.

We can clearly see that the expected value is a function of the variability of the joint venture's payoff $\left(x_{u}-x_{d}\right)$. The larger the volatility, the larger the variability of the possible payoffs and therefore, the expected value in the binomial tree for the acquirer firm will increase directly with the level of uncertainty reflected in the two states of nature, $x_{u}$ and $x_{d}$. Another factor that affects the expected value is the initial equity investment, thus the larger the initial investment, the lower the expected value.

Because uncertainties hold with them valuable information, firms hold options in order to exploit the learning potential. The options are value enhancing when managers can improve their decisions as new information is available and uncertainty gets resolved through the passage of time. Thus, if the acquirer firm holds a Put option to sell back its stake at a fixed price, that means it can invest from the beginning a larger portion of the equity share to take full advantage of any upside potential under guaranteed circumstances. Chi and Nystrom (1995) offer an explanation for exit delay under certainty. Thus, greater uncertainty implies higher learning potential and firms will likely continue the current course of action until the costs of such learning outweigh the benefits.

For a better understanding of the deal, let's take a look at the target firm:

Given the states of nature at $t=2$, the target firm's payoffs can be as follows:

$$
\begin{aligned}
& \mathrm{w}_{\mathrm{u}}=\left[\left(1-\beta_{\mathrm{u}}\right)(1-\mathrm{s}) \mathrm{aI}_{0} ;(1-\mathrm{s}) \mathrm{x}_{\mathrm{u}} ; \mathrm{x}_{\mathrm{u}}-\mathrm{sbI}_{0}\right] \\
& \mathrm{w}_{\mathrm{d}}=\left[\left(1-\beta_{\mathrm{d}}\right)(1-\mathrm{s}) \mathrm{aI}_{0} ;(1-\mathrm{s}) \mathrm{x}_{\mathrm{d}} ; \mathrm{Sx}_{\mathrm{d}}-\mathrm{sbI}_{0}\right]
\end{aligned}
$$


The target firm's expected payoff is:

$W_{0}=\left[p w_{u}+(1-p) w_{d}\right] e^{-d r(t)}-(1-s) I_{0}+\Phi$

If the price of the target firm $(x)$ will be negotiated at a later date and after the state of nature is revealed, the option is more valuable to the partners as the preassessment of the value of the Put option varies heavily when signing the contract. The acquirer firm can invest only a small portion, let's say s\%, and give the Put option to the target firm without paying the premium for the Put option. This strategy will heavily depend on the ex-ante assessment of the bargaining power of each partner at a later date.

Thus, the acquirer firm saves money from not paying the Put premium $\Phi$ and its expected payoff becomes:

$V_{0}=\left[p v_{u}+(1-p) v_{d}\right] e^{-d r(t)}-s I_{0}$

while the target firm is in the possession of a strategic Put option and its expected payoff is:

$W_{0}=\left[p w_{u}+(1-p) w_{d}\right] e^{-d r(t)}-(1-s) I_{0}+\Omega$

where $\Omega$ represents the strategic Put option which gives the right to sell its shares to the acquirer firm according to the conditions stipulated in the Put option clause. 


\begin{tabular}{|c|c|c|}
\hline Acquirer's situations: & High bargaining power & Low bargaining power \\
\hline Small initial investment & Give Put option to target firm & Keep a Call option \\
\hline Large initial investment & Keep the Put option & Keep the Put option \\
\hline Table 1 & \\
\hline
\end{tabular}

Therefore, it remains true that if the bargaining power of the acquirer firm is greater than the bargaining power of the target firm, the acquirer firm can make a small initial investment and grant the Put option to the target firm. The acquirer firm will do that if it is convinced that the value of the target firm will deteriorate in time and the target firm will be forced to negotiate under weak bargaining power.

Due to this strategy the acquirer firm also saves money if when acquiring s\% of shares it negotiates as an initial pre-assessment value of the target firm $\left(I_{0}\right)$ which is lower then its current market value. The above analysis suggests that both partner firms must see an asymmetry between their ex-ante valuations to accept a Put option clause in the joint venture contract. These strategic options add value when managers can identify them, assess them, decide which ones are optimal and exercise or let them expire.

\section{The beginning and the end of a strategic alliance}

The rhythm of change in today's competitive automotive markets pressed companies to search for continual reorganization through mergers, acquisitions and strategic alliances. In order to make a good deal, potential partners must be able to satisfy their own needs, desires and goals. Ultimately, the key to any thriving merger, alliance or acquisition is to have the right mix of factors in place for both partners. To be successful 
in an alliance, partners have to take into account the following motives: cost savings, revenue enhancements, economies of scale, tax benefits, asset striping, process improvements, financial engineering, and control of the markets as well as managerial rewards. Besides those factors mentioned above, emotional mood and greed also play strategic roles.

For the past two decades, U.S. automakers have lost more than $20 \%$ market share to Japanese and Korean automakers. Globalization brought more foreign car manufacturers closer to markets with higher demand, avoiding entry barriers and high costs. The U.S. industry loss in market share can be explained by the inability of U.S. car manufacturers to rapidly adapt to relative changes in price, size, power, operating cost, transmission type, reliability and body type. ${ }^{18}$ Although, subtle attributes like the feel of a stereo knob and a shiny wood-plastic interior can affect consumer preferences, rising health care and pension costs as well as undervalued currencies have also been major contributing factors. Meanwhile, foreign companies responded faster to all the changes in the industry by hiring younger, non-union workers.

The focus of our discussion is the GM-Fiat agreement that started in 2000, when companies signed the joint venture agreement, through February 14, 2005, when the alliance was dissolved. The first sign that Fiat Auto had tackled a different strategy characterized by a wider spread of shareholding and management power took place in 1998, when Giovanni Agnelli left the presidency of Fiat and was replaced by Paolo Fresco, previously vice-president of the U.S.-owned General Electric. The Agnelli family's long emotional attachment to the car business and their refusal to give up

\footnotetext{
${ }^{18}$ Train \& Winston (2006)
} 
control $^{19}$ did not strengthen Fiat's international position, nor did it increase shareholders' wealth. Although Fiat perfectly understood that only through a strong partnership it could stay competitive internationally, many agreements with European producers failed due to the Agnellis' fear of losing power.

On March 13, 2000, after many months of talks with GM, Fiat SpA announced the agreement between GM and Fiat, with General Motors acquiring 20\% of Fiat Auto's capital stock and Fiat purchasing an interest of about $6 \%$ in General Motors. It was an equity swap which did not take place at market values, but rather on the basis of the evaluation of the company branches which were conferred. On July 24, 2000, all juridical aspects of the agreement had been concluded with the formation of Fiat-GM Powertrain, which started manufacturing engines and gearboxes, and GM-Fiat Worldwide Purchasing, which specialized in purchasing. After the EU authorized the deal on September 13, 2000, the Board of Directors and the main top executives of two 50/50 joint companies were appointed. The two joint ventures, Fiat-GM Powertrain B.V. which was based in Turin - and GM-Fiat Worldwide Purchasing B.V. - with operational headquarters in Ruesselsheim - became fully operational at the beginning of January 2001. The alliance was geographically limited to South America and Europe.

The perfect symmetry of the deal emphasized a strategic alliance focused on both short and long term objectives of being partners in costs, but competitors in the markets. Among those short term objectives were those focused on the reorganization of parts and purchasing activities, cost reduction, product quality enhancement and bargaining power with suppliers. Both GM and Fiat were able to concentrate on building a common

\footnotetext{
${ }^{19}$ Two past possible mergers failed due to the Agnellis' reluctance to give up control, with Ford in 1985 and with Chrysler in 1990.
} 
architecture which will allow them to take advantages of deeper knowledge base and to emphasize the uniqueness of each brand. According to the projections of the companies' management, the new "synergies" between Fiat and GM were expected to lead to savings in the purchase of other components of USD 1.2 billion per year starting from the third year and USD 2 billion from the fifth year. Overall, the savings synergies would place GM and Fiat on a different competitive level in terms of increasing market share and enhanced profitability. Furthermore, the clauses on Fiat's autonomy in the agreement allowed the Agnelli family the necessary time to wait for a new generation to play an important role within the company.

On the financial side, following the equity swap, the Fiat group became GM's second-largest shareholder (the majority of the shares are in the hands of a U.S. investment fund) and its leading industrial partner. The financial agreement consisted of a Put option clause which gave Fiat the option, but not the obligation to sell - not sooner than three and half years, and not later than nine years from the signature of the agreement - the remaining $80 \%$ of its shares to GM, which will have a first option to purchase them. Since they signed the agreement, GM and Fiat's finances took a turn for the worse. Fiat's loss record from 2002 led to a widespread restructuring program while GM continued struggling with the loss of market share and increasing health-care costs in the United States.

In May 2002, under pressure from creditors, Fiat signed an agreement with Capitalia, Banca Intesa, San Paolo IMI and Unicredito to improve its financial position. In March 2003, Fiat sold to the four banks mentioned above a 51\% interest in Fidis Retail Italia, a Fiat Group company that provides credit to consumers in Europe for the purchase 
of motor vehicles, a move which knocked about 6 billion Euros off its gross debt. In a way to reach the promised debt level of $\$ 23$ billion dollars gross borrowing by the beginning of 2003, Fiat sold the Brazilian financing unit for $\$ 800$ million as well as its near 6\% stake in GM for $\$ 1.16$ billion. On March 22, 2003 Fiat also sold Toro Assicurazioni to de Agostini Gropu for 2.4 billion Euros which cut the Group's net debt by about 1.4 billion Euros. Though GM had the first call to buy the financing arm Fidis, it passed it up. GM together with Fiat made a statement that "the put option wasn't affected by the sale of $6 \%$ of GM stock," but not long after this event GM continued arguing strongly that Fiat invalidated the Put option when it recapitalized the company, which halved GM's stake in Fiat, and sold off its Fidis financing arm.

In March 2003, Standard and Poor's Rating Services, Fitch Ratings and Moody's Investors Services downgraded Fiat's LT debt, medium tem debt and ST commercial paper. In 2004, psychological battles, lingering legal disputes and finally a lack of a deal had brought an increased volatility for both companies.

After many talks, CEOs of both companies understood that none would gain from a protracted legal dispute which will negatively affect their workers, investors, car markets and customers. They decided a compromise would be the best outcome. On February 13, 2005, Fiat SpA and General Motors dissolved their five-year partnership, with GM paying the Italian group Euro 1.55 billion ( $\$ 2$ billion USD) in cash to avoid not only having to buy loss-making Fiat Auto, but also to be stuck with $\$ 5.3$ billion in debt and pension obligations for tens of thousands of aging Italian workers. Without a doubt, legal disagreements would have affected GM and Fiat's workers, investors, car markets and customers. GM returned its 10 percent stake in Fiat's auto division and the two 
carmakers dismantled their joint venture that manufactured engines and transmissions. According to the CEOs' declarations, both companies would continue to cooperate on engine production, development of vehicle programs and in other fields. Thus GM avoided taking on an ailing company and preserved its credit rating. Fiat received a lump sum of money which temporarily helped to bring its financial situation within acceptable limits.

\section{GM's partial acquisition of Fiat: Valuation of a strategic Put option}

To assess the correct market value of such a joint venture contract, we must analyze if all the contractual clauses and, especially the Put option clause, added value and if so, how much. In March 2000, GM acquired 20\% of the equity in Fiat for $\$ 2.4$ billion USD. Basically, GM swapped $5.1 \%$ of its shares for $20 \%$ of Fiat shares. This implied that the equity value for Fiat was $\$ 12$ billion USD. However, the price of a Fiat stock that day was $\$ 36$ per share giving a market capitalization of $\$ 16,336,312,500$ USD for Fiat. As part of the deal, GM granted Fiat a Put option to force GM to buy the rest of the shares of Fiat. The contract stipulated that Fiat holds a Put option which gives the right to sell its $80 \%$ remaining shares to GM anytime after 4 years from signing the contract and before the ninth anniversary. If Fiat decided to sell its shares to a third party, the agreement granted Fiat the right to drag along GM. However, GM had the right to tag along Fiat in the sale to a third party. The contract could be extended up to a period of 19 years. After that period GM, the Put and other rights would expire and GM would have the right to demand of Fiat the listing of Fiat in an IPO. 
Let's assume that the acquisition was possible any time after 4 years and before the ninth anniversary. The first 4 years represented a blackout period when the option could not be exercised ${ }^{20}$. The blackout period would prevent Fiat from exercising sub optimally and would also allow GM to not undervalue a potentially lucrative acquisition target. The binomial valuation approach requires the following inputs:

-The security price V is the expected value of the target firm's shares. Let's assume that in 2000 Fiat was fairly valued and the value of the firm was $\$ 12$ billion. However, GM has to acquire only the rest $80 \%$ of the shares and this represents $\$ 9.6$ billion. According to the contract, the exercise price is established through negotiation at the fair market value at a later date. If GM and Fiat do not agree on the valuation, the fair market value will be determined by either two or four independent investment banks.

-The strike price represents the acquisition price of the $80 \%$ of equity agreed by the partner firms. For now, we assume that the exercise price for the Put option is equal to $\mathrm{X}=\$ 9.6$ billion. However, the price is determined by negotiation at the time of acquisition.

-Annualized volatility is $50.10 \%$ based on Fiat's historical daily closing prices from CRSP database for the past 5 years. The volatilities are calculated using the standard deviation of the natural logarithmic relative returns, annualized for a year and then averaged.

-Life: The option will expire $\mathrm{t}=9$ years from the initial acquisition of $20 \%$ of equity

The time steps are the number of branching events in a lattice.

-Dividend payments are excluded.

\footnotetext{
${ }^{20}$ This option presents the characteristics of a Bermudan option that is exercisable at any time prior to maturity except during specific blackout periods.
} 
-The annualized risk free rate is based on the 10-year US Treasury note of $6.36 \%$.

Because we have a Put option, we consider this as an American Put option that has to be valued using a binomial model since a premature exercise might be reasonable. The question is, how much is Fiat worth to GM (specifically the rest of $80 \%$ of its shares,) and is $\$ 9.6$ billion a good price.

Because Fiat stocks are fairly volatile and the dynamic automotive sector is burdened with uncertainties, GM negotiated a protective Put option to hedge its downside risks. According to the well known JV practice, if target firm (Fiat) does not operate up to expectations, an abandonment option can be executed and target firm (Fiat) can be sold for its intellectual property. However, given that the stock price based on the swap was around \$26 and Fiat stock was trading at \$36 in March 2000, GM gave that Put option to Fiat. In this case, Fiat had an option to force GM to buy its shares. The contract stipulated that for the duration of the agreement, the Put option cannot be executed for the first 4 years. This means that for the first 4 years there are some blackout steps whereby the option holder can only keep the option open. It is advisable to take into account the blackout periods to correctly adjust the value of the option while accounting for the nonmarketability condition. $^{21}$

The analysis applies both a customized binomial lattice and a closed-form BlackScholes model for comparison and benchmarking purposes. We'll value the Put option under the conditions mentioned above (see Appendix).

\section{| Please Insert Figure 1 About Here|}

Figure 2 illustrates the underlying asset lattice based on the evaluation of the underlying asset value in time due to asset's volatility. These up and down moves depict

\footnotetext{
${ }^{21}$ We value the Put option using the Real Options Super Lattice Solver software by Johnathan Mun (2006)
} 
the fact that value of underlying asset can be anywhere between $\$ 43.15$ and $\$ 2.14$ billion at the end terminal node.

\section{| Please Insert Figure 2 About Herel}

The second lattice in the binomial approach is reflected in figure 3. Through backward induction and using risk-neutral probabilities we determine the value of the option at time zero being equal to $\$ 2.9979$ billion.

\section{| Please Insert Figure 3 About Herel}

Notice that for the binomial lattice, the higher the number of time steps, the more accurate the results are. The American option (3.23) is worth more than the Bermudan option (2.9979) due to the fact that the latter can't be exercised during the blackout period. At the limit, if we increase the number of steps, the value of the Put option approaches the value of the closed form solution.

Let's change the assumptions and presume that due to the uncertain nature of the joint venture development and market demand, management of GM decided to create an abandonment option (see Figure 4).

\section{| Please Insert Figure 4 About Herel}

Thus, Fiat would agree to a buyback provision of GM's initial investment of \$2.4 billion. The decision at maturity is to decide if the option should be executed, putting back the initial investment to Fiat and receiving its initial investment, or not to execute and remain in the joint venture. The execution of option is prohibited during the blackout period, but allowed anytime after that and before maturity. This $\$ 2.4$ billion salvage value is fixed until the option expires. Using a Bermudan option with 100-step lattice on 9 years, where the blackout period covers the first 4 years, the Bermudan abandonment 
option results show a value of $\$ 9.85$ billion (Figure 5), indicating that the value of the option is $\$ 0.25$ billion (\$9.85-\$9.60) (Figure 6). Hence, maximum price GM should have paid Fiat for this option under these conditions would have been on average $\$ 0.25$ billion.

\section{| Please Insert Figure 5 and 6 About Here|}

From a valuation perspective, collaboration between GM and Fiat in Latin America and Europe in power train operations, back office facilities for automotive financing and material purchasing activities was expected to generate significant savings. It was predicted that the JV will reach efficiency gains by cutting jobs as well as supplying engines and transmissions to other car producers. Existing common platforms between the two companies were expected to reduce development costs while new cars launched on the market would become more effective sources of income. Although executives from both companies had made statements that the savings from the deal have outrun the costs, those savings were not easily broken out on automakers' balance sheets. This deal meant more for Fiat than for GM, in an industry where dynamic changes and economies of scale are the rule. In a world where even the biggest and the strongest are not assured of survival, at the end of the 90s, Fiat was barely treading water.

Another key issue of this joint venture was the design of the contract by using a Put option agreed to by former chairman Jack Smith when he struck a deal to acquire part of Fiat in 2000. That deal was designed to enhance GM's European operation by saving money through joint purchasing and product development. According to various newspapers and magazines, the Italians held out for the Put option that GM executives have long said would never be exercised because the Italians would never want to sell off the entirety of their principal automaker. 
Thus, GM paid $\$ 2.4$ billion for $20 \%$ of Fiat equity and gave a Put option to Fiat worth $\$ 2.99$ billion. This way, GM, being in a strong bargaining position, it used the Put option as a currency, avoiding paying any premium had it held any Call or Put options. Because Fiat wasn't on equal negotiation footing in terms of a wide global presence, having a Put option just emphasized a weak bargaining power. As analysis in chapter III suggests, although in the beginning GM negotiated aggressively on a high bargaining power position, in the end, GM had to pay approximately $\$ 2$ billion just to get out of the deal.

\section{Summary and Conclusions}

Real life shows us that each business is unique, in terms and opportunities, and no standard financial model is sufficient to value and optimize all the requirements, opportunities and desires. Yet good negotiation skills, robust financial due diligence, exante preparation and exceptional risk assessment contribute to a better valuation.

Because flexibility remains one of the attractive aspects of a joint venture, we use a real options approach to model it. The application of option thinking within a joint venture contract emphasizes the need to identify the clauses where risks can be mitigated. We've shown that a successful strategic option requires a customized real-option valuation model to lessen the conflict between the conclusion of strategic analysis and a real option approach. Synergies, as the source of value creation in an acquisition, should always be complemented by an analysis of strategic options. This analysis can be used as an educational tool to learn about each partner's commitment to a successful deal. Using 
a binomial model we articulate how a strategic Put option clause can add value to the joint venture. Our analysis suggests that both partner firms must see an asymmetry between their ex-ante valuations to accept a Put option clause in the joint venture contract. The value of the joint venture increases as the ex-ante anticipation of ex-post diverging valuation gets larger. These strategic options add value when managers can identify them, assess them, decide which ones are optimal, and exercise or let them expire. Using the GM-Fiat deal, we show how the Put option can be used as a currency if the acquirer firm has a strong bargaining power. Like an engaged couple that never makes it to the alter, pricing correctly the strategic options embedded in the contract will save money, time and missed opportunities. Insights from options-based analyses should improve not only the estimates of asset value, but also the decision-making process. Both firms will have the possibility to initiate follow-up projects that can be value enhancing. The paid "premium" from working together will create a valuable strategic learning option with the upside potential to not make the same wrong decisions in the future. 


\section{References}

Amran, M. and Kulatilaka, N., 1999, Real Options: Managing Strategic Investment in An Uncertain World, Harvard Business School Press, Boston.

Berg, S. and Friedman,P., Joint Ventures in American Industry: An Overview, Mergers and Acquisitions, 13, 1978a, pp. 28-41.

Bleeke, Joel, and David, Ernst ,1995, Is Your Strategic Alliance Really a Sale?, Harvard Business Review, January/February:97-105.

Boyle,S.E., 1968, Estimate of the Number and Size Distribution of Domestic Joint Subsidiaries, Antitrust Law and Economics Review, 1, pp.81-92.

Chang, S-J. and Rosenzweig, M. ,2001, The Choice of Entry Mode in Sequential Foreign Direct Investment, Strategic Management Journal, 22:747-776.

Chemla, G., Habib, M. and Ljungqvist, A.P., 2004, An Analysis of Shareholders Agreements. LSE Working paper RICAFE No. 006.

Chi, T. and McGuire, D., 1996, Collaborative Ventures and Value of Learning: Integrating the Transaction Cost and Strategic Option Perspective on the Choice of Market Entry Modes, Journal of International Business Studies, Vol. 27, No. 2, $2^{\text {nd }}$ Qtr., pp. 285-307.

Chi, T. and Nystrom, P. C. 1995, Decision Dilemmas Facing Managers - Recognizing the Value of Learning While Making Sequential Decisions. Omega-International Journal of Management Science, 23(3): 303-312.

Chi, T. and Seth, A., 2004, Exploiting Complementary Capabilities: a Dynamic Model of the Choice of Investment Mode, Working paper, University of Kansas, University of Illinois.

Copeland, Tom and Antakarov, V., 2001, Real Options. NewYork: Texere.

Coy, P., 1999, Exploiting Uncertainty: The "Real Options" Revolution in Decision Making, Business Week, June 7, pp. 1180124.

Dixit, A. K. and Pindyck, R. S.,1994, Investment Under Uncertainty. Princeton.

Gutterman, A., 2002, A Short Course in International Joint Ventures : Negotiating, Forming \& Operating the International JV, World Trade Press, Novato, CA, USA.

Hagedoorn, John and Sadowski, Bert,1999, Transition from Strategic Technology Alliances, Journal of Management Studies, 36:1, January:87-107. 
Harrigan, Kathryn Rudie., 1986, Managing for joint venture success, Lexington Books, USA.

Herzfeld, E. and Wilson, A., 1996, Joint Ventures, Jordans.

Jemison, D. and Sitkin, S., 1986, Corporate acquisitions: A Process Perspective, Academy of Business Review.

Kester, W. C., 1984, Today's Options for Tomorrow's Growth, Harvard Business Review, March/April, pp. 153-160.

Kogut, Bruce, 1988, Joint Ventures: Theoretical and Empirical Perspectives, Strategic Management Journal, Vol. 9, No. 4, Jul - Aug 1988, pp. 319-332.

Linklaters and Paines Nightingale, C., 1990, Joint Ventures, Longman.

Mason, S. P. and Merton, R. C. , 1985, The role of Contingent Claims Analysis in Corporate Finance, Recent Advances in Corporate Finance, E. Altman and M. Subrahmanyam, eds, Homewood, IL, R.D.Irwin.

Mead,W.J., 1967, Competitive Significance of Joint Ventures, Antitrust Bulletin.

McConnell, J and Nantell, J., 1985, Common Stock Returns and Corporate Combinations: The Case of Joint Ventures, Journal of Finance, 40, pp. 519-536.

Mun, J., 2006, Real Options Analysis, Wiley Finance, Second edition, New Jersey.

Pate,J.L., 1969, Joint Venture Activity, 1960-1968, Economic Review, Federal Reserve Bank of Cleveland, pp. 16-23.

Reich, Robert B and Mankin, E. D. ,1984, Joint Ventures with Japan Give Away Our Future, Harvard Business Review, March-April, pp. 78-86.

Schildt, H. A. and Laamanen, T., 2006, Who Buys Whom: Information Environments and Organizational Boundary Spanning Through Acquisitions, Strategic Organization, May 1, 4(2): pp. 111-133.

Singh. H. and Montgomery, C. A., 1987, Corporate Acquisition Strategies and Economic Performance, Strategic Management Journal 8, pp. 377-386.

Sirower, M., 1997, The Synergy Trap. Free Press: New York.

Smith, T. A., 2003, Real Options and Takeovers, Emory Law Journal, Vol. 52, No. 4, pp. 1815-1846.

Train, E. Kenneth and Clifford Winston, Seth, 2006, Vehicle Choice Behavior and the Declining Market Share of U.S. Automakers, Forthcoming, International Economic Review. 
Trigeorgis, L. and Mason, S. P., 1987, Valuing Managerial Flexibility, Midland Corporate Finance Journal, 5, Spring, pp. 14-21.

Trigeorgis, L., 1996, Real options. Managerial Flexibility and Strategy in Resource Allocation. The MIT Press, Cambridge, MA.

Appendix

\begin{tabular}{|c|c|c|c|}
\hline \multicolumn{4}{|c|}{ Option Valuation Audit Sheet } \\
\hline \multicolumn{2}{|l|}{ Assumptions } & \multicolumn{2}{|l|}{ Intermediate Computations } \\
\hline PV Asset Value (\$) & $\$ 9.60$ & Stepping Time (dt) & 0.0900 \\
\hline Implementation Cost (\$) & $\$ 9.60$ & Up Step Size (up) & 1.1622 \\
\hline Maturity (Years) & 9.00 & Down Step Size (down) & 0.8604 \\
\hline Risk-free Rate (\%) & $6.36 \%$ & Risk-neutral Probability & 0.4815 \\
\hline Dividends (\%) & $0.00 \%$ & & \\
\hline Volatility (\%) & $50.10 \%$ & Results & \\
\hline Lattice Steps & 100 & Lattice Result & 3.00 \\
\hline Option Type & Bermudan & & \\
\hline Terminal Equation & \multirow{3}{*}{\multicolumn{3}{|c|}{$\begin{array}{l}\operatorname{Max}(\text { Cost-Asset,0) } \\
\operatorname{MAX}(\operatorname{Max}(\text { Cost-Asset,0), @@) } \\
@ @\end{array}$}} \\
\hline Intermediate Equation & & & \\
\hline Intermediate Equation (Blackouts) & & & \\
\hline
\end{tabular}

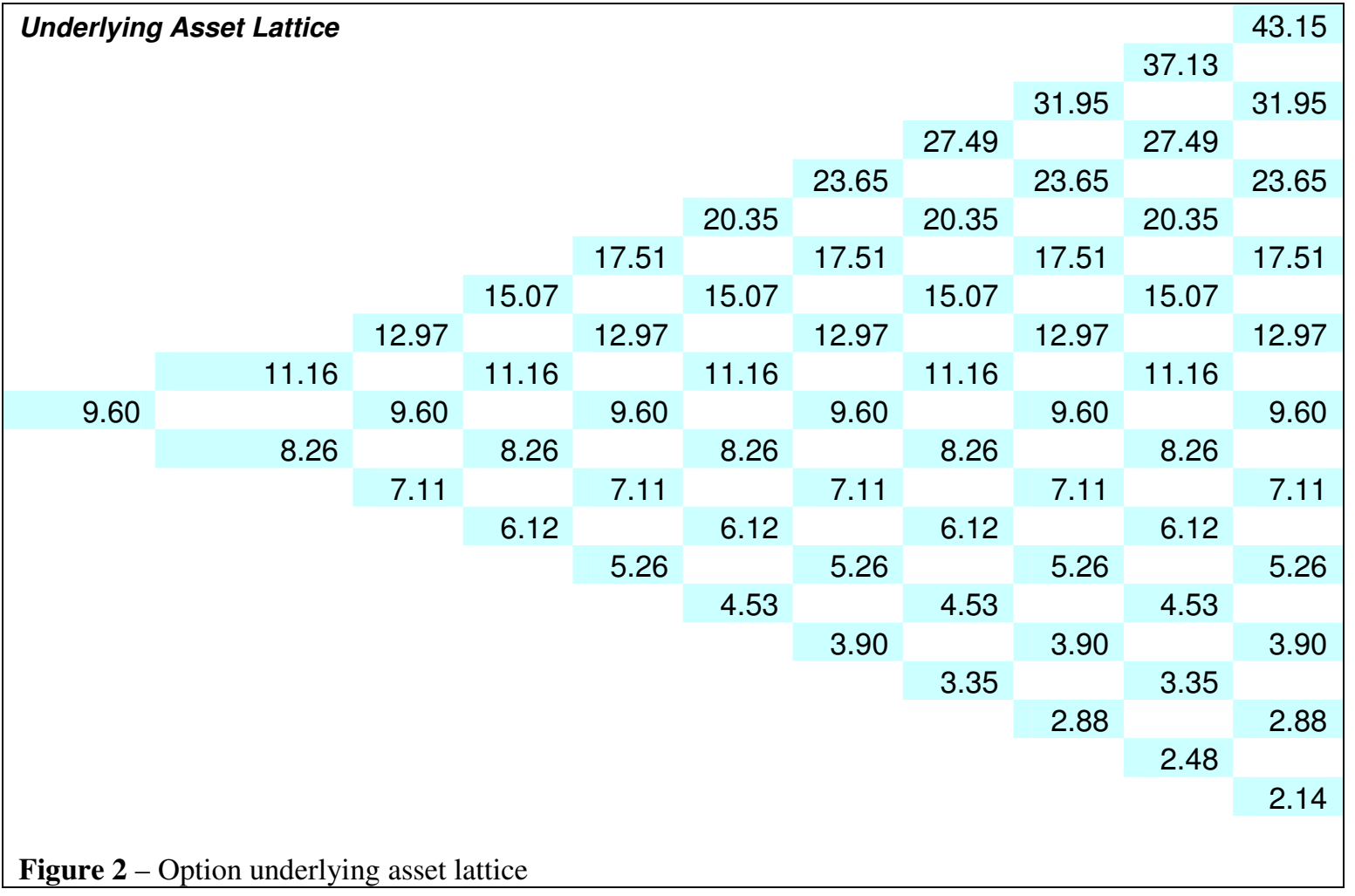




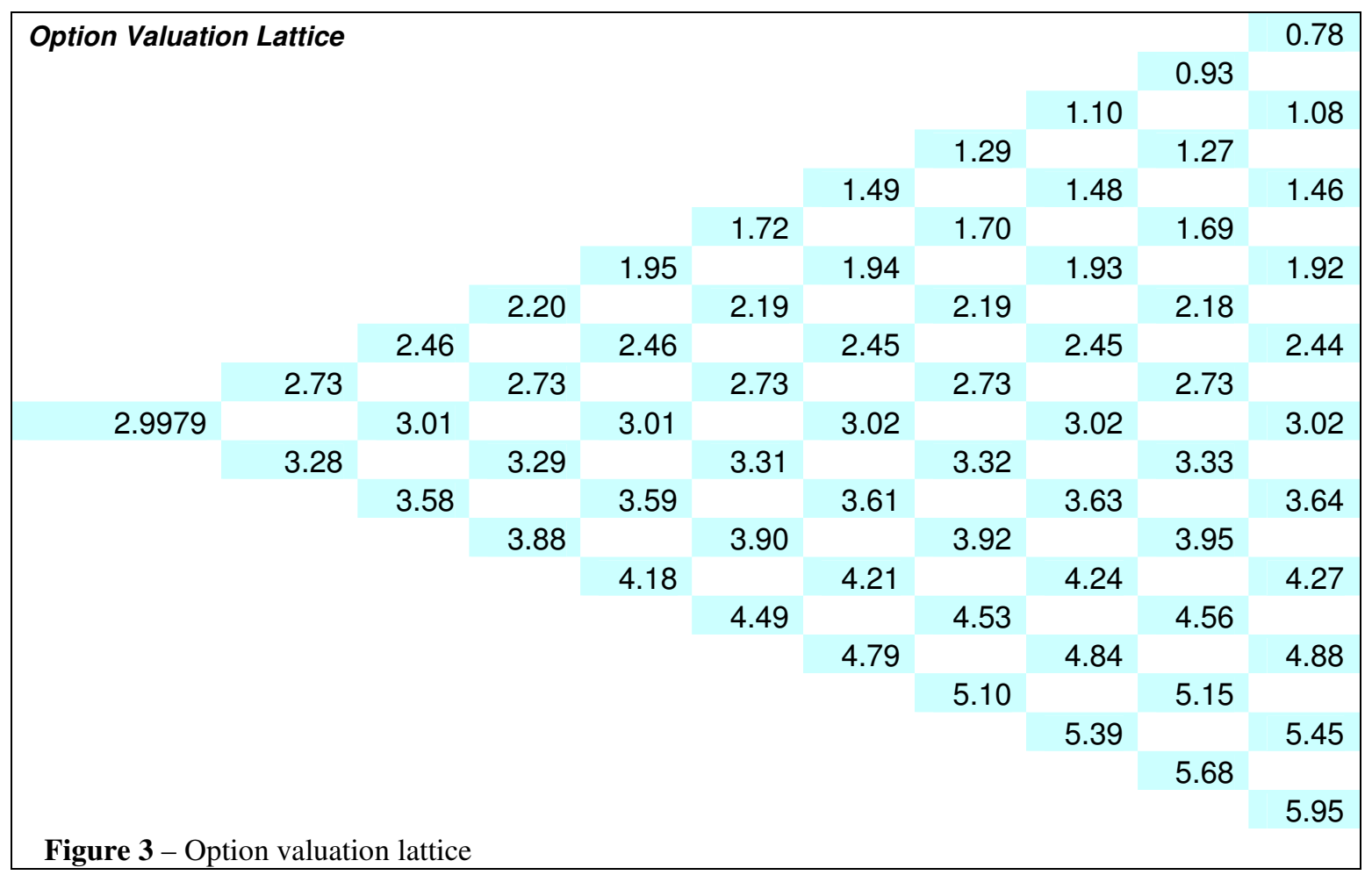

\section{Abandonment Option Valuation Audit Sheet}

\section{Assumptions}

PV Asset Value (\$)

Implementation Cost (\$)

Maturity (Years)

Risk-free Rate (\%)

Dividends (\%)

Volatility (\%)

Lattice Steps

Option Type

Terminal Equation

Intermediate Equation

Intermediate Equation (Blackouts)

\section{Custom Variables}

Name salvage

Value $\quad 2.40$

Starting Step

Figure 4 - Abandonment option valuation parameters

@@
Intermediate Computations

Stepping Time ( $d t)$

Up Step Size (up)

1.1622

Down Step Size (down)

Risk-neutral Probability

0.8604

0.4815

Results

Lattice Result

9.85

Max(Asset, Salvage)

MAX(Max(Asset, Salvage), @@) 


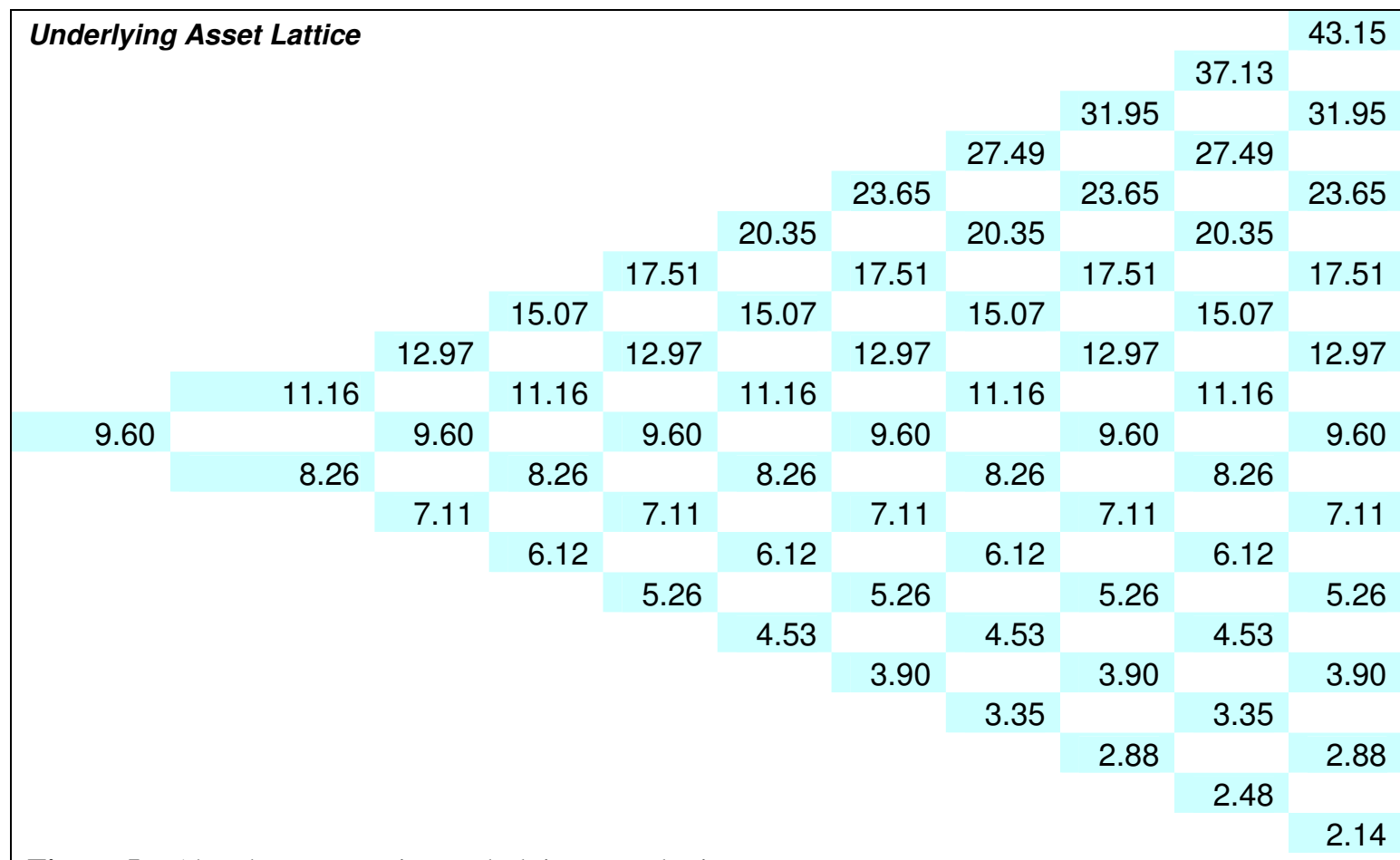

Figure 5 - Abandonment option underlying asset lattice

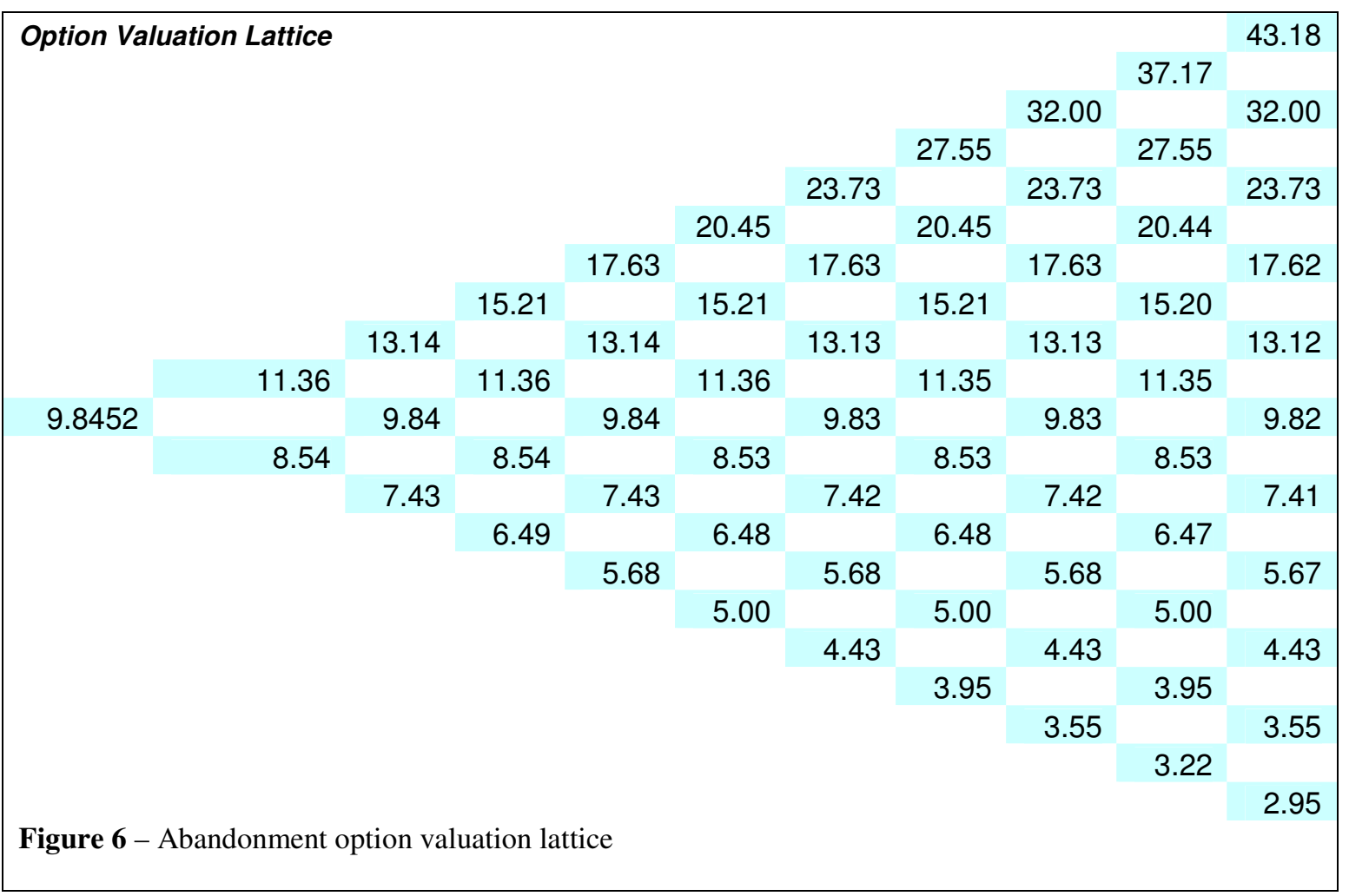


